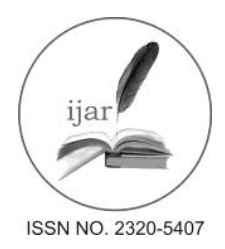

Journal homepage: http://www.journalijar.com

Journal DOI: $\underline{10.21474 / I J A R 01}$

INTERNATIONAL JOURNAL

OF ADVANCED RESEARCH

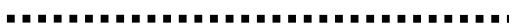

RESEARCH ARTICLE

\title{
A STUDY ON RELATIONSHIP BETWEEN BMI AND PREVALENCE OF FLAT FOOT AMONG THE
} ADULTS USING FOOT PRINT PARAMETERS.

\author{
K.Vijayakumar ${ }^{1}$, Dr.S.Senthil kumar ${ }^{2}$, Dr.Rameshkumar Subramanian ${ }^{2}$. \\ 1. Research scholar, Department of Anatomy, Sri Ramachandra University, Chennai, India. \\ 2. . Professor of Anatomy, Sri Ramachandra University, Chennai, India.
}

\section{Manuscript Info}

Abstract

Manuscript History:

Received: 18 March 2016

Final Accepted: 19 April 2016

Published Online: May 2016

Key words:

*Corresponding Author

Dr.S.Senthil kumar.

Copy Right, IJAR, 2016... All rights reserved.

\section{Introduction:-}

Obesity is a state where there is an abundant storage of adipose tissue that has a denying effect over the health, according to world health organization (WHO) in the year 2014, 600 million were obese in that 1.9 billion were young adults [1,2]. Increased body fat that has been accumulated to an extent that it may have a negative effect on health, leading to reduced life expectancy and/or increased health problems [3]. Every 1 out of 5 adults are suffering from foot pain [4]. Foot pain is reported commonly in overweight and obese individuals [5] and increased BMI [6]. Flat foot is a biomechanical disorder in which the arches of the foot becomes flattened, and alters the transmission of forces from superior extremities to the ankle and the foot [7]. Excessive fat deposition leads to increased loading of pressure over the arches causing flat foot $[8,9]$. Obesity, illness, faulty biomechanics and prolonged stress to the feet can develop flat foot [10]. In obese individuals there are changes in foot due to excessive mechanical loading during walking [11]. Footprint parameters act as an essential tool in assessing the differences in foot morphology and foot types [12-20]. Individual wide variations of foot arch can be revealed using foot print parameters [13]. These foot print parameters are systematically used to assess the configuration of the arch [12, 13, 17-19]. Arch height is a simple and effective parameter in assessing the medial longitudinal arch height [21]. Footprint angle (FA) and Chippaux-smirak index (CSI) are the most effective parameters to assess the characteristics of foot morphology [22, $23,25,26]$. Studies have shown the prevalence of flat foot in general population but the distribution of the flat foot problems are high in overweight and obese individual, this lacunae of knowledge in literature about the obese individuals foot problems can be achieved by this study. Hence the aim our study is to evaluate the prevalence of flat foot in normal, overweight and obese individuals and to establish the relationship between BMI and morphology of the foot using foot print parameter. 


\section{Material and methods:-}

The study was conducted in 412 healthy volunteers and grouped based on the body mass index (BMI) into underweight (24males and 22females), desirable weight (69males and 65females of BMI<25), overweight (52males and 32females BMI 25-29.9), obese (58males and 45females BMI 30-39.9) and in morbid obese (26males and 19 females BMI 40 and above), between the age group 25years to 40 years. Individuals with open wound or recent surgery to their feet were excluded. The following details were took from each subject: name, age, gender, height $(\mathrm{cm})$, weight(wt), lower limb length, physical activities and its duration in hours per week. Body mass index (BMI) was calculated as weight $(\mathrm{kg})$ divided by square of the height in meter. In full weight bearing foot prints of both feet were impregnated using non irritant blue ink in a $60 \mathrm{~cm}$ length $\mathrm{x} 60 \mathrm{~cm}$ breadth of paper. From each impregnated foot prints, the parameters arch (Clarke) index, Chippaux-smirak index, Staheli index, and arch index were measured. All the participants in the study were obtained by the formal informed consent, and this study was approved by institutional ethical committee (IEC)- NI/14/DEC/44/93.

\section{Outcome measures:-}

* Arch (Clarke) index (ABC angle) (fig:1): Line A is the angle at the medial most margin of the forefoot and hindfoot, line B connects the medial side of the foot to the medial most part of the metatarsal region [25,27,28].

* Chippaux-Smirak index $(100 * \mathrm{CD} \backslash \mathrm{AB})(\mathrm{fig}: 2)$ : The ratio between $\mathrm{CD} / \mathrm{AB}$, Line $\mathrm{AB}$ is the wider zone of forefoot and line CD is the narrowest width of the midfoot [12,25,27,28].

* Staheli index (CD/EF) (fig:3): The ratio between CD/EF, line CD is the narrowest width of the midfoot and line $\mathrm{EF}$ is the wider zone of the hindfoot $[25,26,28,35]$.

* Arch index E/(D+E+F) (fig:4): This is the ratio of the area of toeless footprint, a line joining the middle of the $2^{\text {nd }}$ toe to the posterior most midpoint of the heel. Two perpendicular lines to this line divides the footprint into 3 equal parts [24,25,27,29].
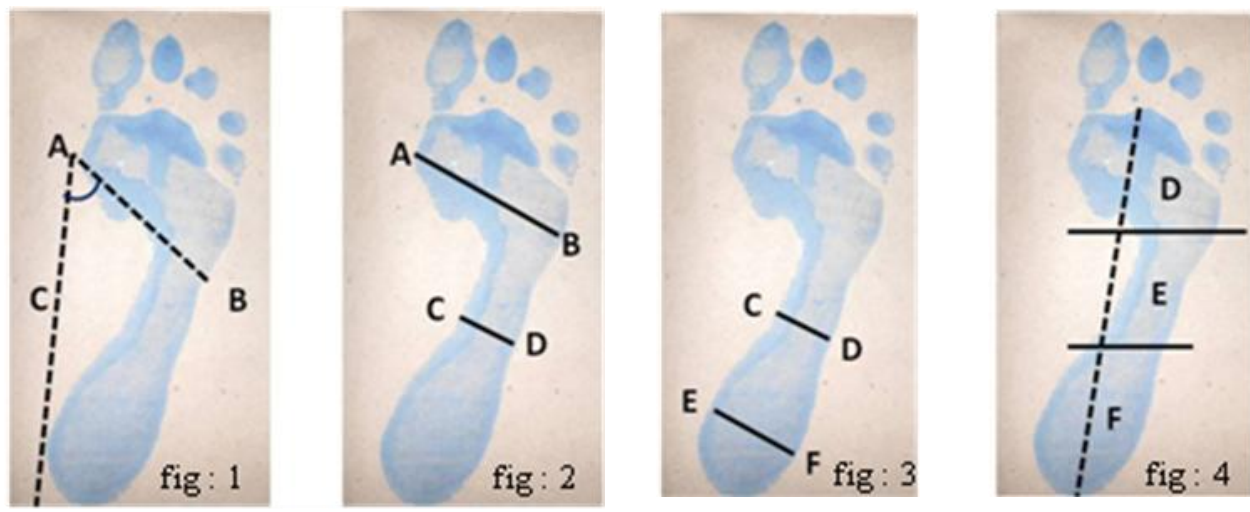

Table: 1:- difference between normal foot and flat foot.

\begin{tabular}{|l|c|c|}
\hline \multicolumn{1}{|c|}{ Parameters } & Normal range & Flat foot \\
\hline Clarkes index & $31^{\circ}-45^{\circ}$ & $>45^{\circ}$ \\
\hline Chippaux-smirak index & $25 \%-45 \%$ & $>50 \%$ \\
\hline Staheli index & $0.5-0.7$ & $>0.7$ \\
\hline Arch index & $0.21-0.28$ & $>0.28$ \\
\hline
\end{tabular}

\section{Results:-}

The observations were statistically analyzed using SPSS 20 version. Comparison of the groups were done between the variables, and the $\mathrm{p}$ value $<0.05$ were considered as statistically significant. The results thus obtained are tabulated in table 2, 3, 4 .

Table: 2:- The characteristics of subjects (Mean $\pm \mathrm{SD}$ ).

\begin{tabular}{|l|c|c|c|}
\hline \multicolumn{1}{|c|}{ Gender } & Height (cm) & Weight (kg) & BMI \\
\hline Males & $174 \pm 5.4$ & $88.9 \pm 20.7$ & $29.33 \pm 4.3$ \\
\hline Females & $162 \pm 3.4$ & $76.4 \pm 16.4$ & $27.45 \pm 4.1$ \\
\hline
\end{tabular}


Table:3:- The prevalence of flat foot in males and females.

\begin{tabular}{|c|c|c|c|}
\hline Gender & No of subjects & Flat foot & \% \\
\hline Males & 229 & 90 & $24.59 \%$ \\
\hline Females & 183 & 82 & $22.04 \%$ \\
\hline Total & 412 & 172 & $46.63 \%$ \\
\hline
\end{tabular}

Table:4:- The prevalence of flat foot based on BMI.

\begin{tabular}{|l|c|c|}
\hline \multicolumn{1}{|c|}{ BMI } & Males & Females \\
\hline Underweight & $24.83 \%$ & $36.36 \%$ \\
\hline Desirable weight & $24.64 \%$ & $32.31 \%$ \\
\hline Overweight & $44.23 \%$ & $56.25 \%$ \\
\hline Obese & $55.17 \%$ & $62.22 \%$ \\
\hline Morbid obese & $73.08 \%$ & $69.95 \%$ \\
\hline
\end{tabular}

The prevalence of flat foot in this study is $24.59 \%$ in males and $22.04 \%$ in females as shown in table:3 and $(\mathrm{p} \leq 0.05)$ that there is strong relationship between BMI and morphology of the foot. When the BMI increases the prevalence of the flat foot also increases. The study population are categorized based on the BMI and the result shows that the prevalence of flat foot is high in males $73.08 \%$ and in morbid obese group as shown in table: 4 .

\section{Discussion:-}

The study was designed to analyze the prevalence of flat foot using foot print based on the BMI. As hypothesized the incidence of flat foot was high among the obese and morbid obese group. Since raised BMI have negative effects over the musculoskeletal system our study limits the focus within the structure of arches of the foot. In our study 412 individuals foot arch were studied it showed that $46.63 \%$ of the subjects had flat arched foot. Raised BMI level is associated with with flat foot and increases the plantar pressure during walking [41, 42]. Studied the footprints of 649 subjects of anambra state between the age group of 18-27 years and stated that $8.9 \%$ of the individuals are affected with flat foot [34]. The author studied the foot morphology and stated the prevalence of low arched and flat arched foot in the study population in our study we have compared the foot morphology with BMI and found a correlation $\mathrm{p}>(0.05)$ between the foot morphology and body composition. Davida louise et al studied the plantar peak pressure of 33 subjects between the BMI and plantar peak pressure during walking and stated that there is an increased plantar pressure in the medial longitudinal arch during walking [40]. [43]Based on denis method the foot print of 228 subjects were screened and found a correlation between the BMI and arches of the foot among the age group of 18-25 years, around $28.61 \%$ individuals found to be having flat arched foot, the author used a Denis method tool to grade the flat foot, in our study we have used Chippaux-smirak index, Clarkes angle, Staheli index, and arch index and we have found and compared the regions of the different regions of the foot. In our study the incidence of flat foot is high in morbid obese males $73.08 \%$ and in morbid obese females $69.95 \%$ morbid obese group is the most affected group in our study, as the BMI raises the incidence of flat foot increases.

\section{Conclusion:-}

The study indicated, increased fat mass over the body causes the raise in the BMI leads an exertion of greater force over the sole of the foot. Obesity not only affects the foot by causing pain it also leads to other musculo-skeletal problems which in turn results in disturbances in walking and other weight bearing activites. In conclusion overweight and obesity has to be reduced to minimize the biomechanical problems. 


\section{Bibiliography:-}

1. https://en.wikipedia.org/wiki/Obesity

2. http://www.cdc.gov/obesity/data/adult.html

3. WHO - overweight and obesity fact sheet N 311 updated January 2015

4. Thomas MJ, Roddy E, Zhang W, Menz HB, Hannan MT, Peat GM: The population prevalence of foot and ankle pain in middle and old age: a systematic review. Pain 2011, 152:2870-2880.

5. Tanamas SK, Wluka AE, Berry P et al. Relationship between obesity and foot pain and its association with fat mass, fat distribution, and muscle mass. Arthritis Care Res 2012; 64: 262-268.

6. Butterworth PA, Landorf KB, Smith SE, Menz HB. The association between body mass index and musculoskeletal foot disorders:a systematic review. Obes Rev 2012; 13: 630-642.

7. Van Boerum DH1, Sangeorzan BJ , Department of Orthopedics and Sports Medicine, Harborview Medical Center, P.O. Box 359798, Seattle,WA 98104,USA.

8. Irving DB, Cook JL, Young MA, Menz HB. Obesity and pronated foot type may increase the risk of chronic plantar heel pain: a matched case-control study. BMC Musculoskelet Disord 2007; 8: 41.

9. Crosbie J, Burns J. Are in-shoe pressure characteristics in symptomatic idiopathic pes cavus related to the location of foot pain? Gait Posture 2008; 27: 16-22.

10. Jahss MH. Spontaneous rupture of the tibialis posterior tendon: clinical findings, tenzgraphic studies, and a new technique of repair. Foot Ankle.Nov-Dec 1982;3(3):158-66.Mann RA. Acquired flatfoot in adults. Clin Orthop Relat Res. Dec1983;46-51.

11. Blaszczyk JW, Plewa M, Cieslinska-Swider J, Bacik B,Zahorska-Markiewicz B, Markiewicz A. Impact of excess body weight on walking at the preferred speed. Acta Neurobiol Exp (Warsz) 2011; 71: 528-540.

12. Cavanagh PR, Rodgers MM. The arch index: a useful measure from footprints. J Biomech 1987;20(5):547-51.

13. Forriol F, Pascual J. Footprint analysis between three and seventeen years of age. Foot Ankle Int 1990;11(2):101-4.

14. Garcia-Rodriguez A, Martin-Jimenez F, Carnero-Varo M, Gomez-Gracia E, Gomez-Aracena J, FernandezCrehuet J. Flexible flat feet in children: a real problem? Pediatrics 1999;103:e84.

15. Gilmour JC, Burns Y. The measurement of the Medial Longitudinal Arch in children. Foot Ankle Int 2001;22(6):493-8.

16. 14.Hogan MT, Staheli LT. Arch height and lower limb pain: an adult civilian study. Foot Ankle Int 2002;23(1):43-7.

17. Rose GK, Welton EA, Marshall T. The diagnosis of flat foot in the child. J Bone Joint Surg 1985;67B(1):71-8.

18. Staheli LT, Chew DE, Corbett M. The longitudinal arch. J Bone Joint Surg 1987;69A(3):426-8.

19. Volpon JB. Footprint analysis during the growth period. J Pediatr Orthop 1994;14(1):83-5.

20. Welton EA. The Harris and Beath footprint: interpretation and clinical value. Foot Ankle Int 1992;13(8):462-8.

21. McCrory JL, Young MJ, Boulton AJM, Cavanagh PR. Arch index as a predictor of arch height. The Foot 1997;7:79-81.

22. Mauch M, Grau S, Krauss I, Maiwald C, Horstmann T: A new approach to children's footwear based on foot type classification. Ergonomics 2009,52(8):999-1008.

23. Razeghi M, Batt ME: Foot type classification: a critical review of current methods. Gait Posture 2002, 15(3):282-291.

24. Xiong S, Goonetilleke RS, Witana CP, Weerasinghe TW, Au EY: Foot arch characterization: a review, a new metric, and a comparison. J Am Podiatr Med Assoc 2010, 100(1):14-24.

25. Shiang TY, Lee SJ, Chu WC.Evaluating different footprint parameters as a predictor of arch height. IEEE Eng Med Biol Mag. 1998;7(6):62-66.

26. Hawes MR, Nachbauer W, Sovak D, et al. Footprint parameters as a measure of arch height. Foot Ankle. 1992;13(1):22-26.

27. Lopez N, Alburquerque F, Santos M,et al. Evaluation and analysis of the footprint of young individuals. A comparative study between football players and non-players. Eur J Anat.2005; 9(3):135-142.

28. Mathieson I, Upton D, Birchenough A. Comparison of footprint parameters calculated from static and dynamic footprints. The Foot 1999; 9(3):145-149.

29. Billis E, Katsakiori E, Kapodistias C, et al. Assessment of foot posture:Correlation between different clinical techniques. The Foot. 2007; 17(2):65-72.

30. Headlee DL, Leonard JL, Hart JM, et al. Fatigue of the plantar intrinsic foot muscles increases navicular drop. J Electromyogr Kinesiol. 2008;18(3):420-425.

31. Urry SR, Wearing SC. Arch indexes from ink footprints and pressure platforms are different. The Foot.2005;15: 68-73. 
32. Wearing SC, Hills AP, Byrne NM, et al.The Arch Index: A Measure of Flat or Fat Feet? Foot Ankle Int. 2004;25(8):575-581.

33. Aydog ST, Demirel HA, Tetik O, et al.The sole arch indices of adolescent basketball players. Saudi Med J. 2004;25(8):1100-1102.

34. Anushri S, Archana T, Gandhi R, Vishwavidyalaya P, Road A. International Journal of Biomedical and Advance Research. 2011;02:166-8.

35. Aydog ST, Tetik O, Demirel HA, et al.Differences in sole arch indices in various sports. Br J Sports Med. 2005;39(5):1-3.

36. Rutherford A. Footprints. J Audiov Media Med. 1983; 6(3):80- 88.

37. A. Garcia-Rodriguez, et al. Flexible flat feet in children: A real problem? Pediatrics. 1999, 103: 84-89.

38. Robbins JM. Recognizing, treating, and prevent in common foot problems. Cleve Clin J Med.2000;67(1):457,51-2,55-6.

39. Kanatli U, Yetkin H, Cila E. Footprint and radiographic analysis of the feet. J Pediatr Orthop. 2001; 21:225-8.

40. O'Brien DL, Tyndyk M. Effect of arch type and body mass index on plantar pressure distribution during stance phase of gait. Acta Bioeng Biomech. 2014;16(2):131-5.

41. Ker RF, Bennett MB, Bibby SR, Kester RC, Alexander RM (1987) The spring in the arch of the human foot. Nature 325: 147-149.

42. Kappel-Bargas A, Woolf RD, Cornwall MW, Mcpoil TG (1998) The windlass mechanism during normal walking and passive first metatarsalphalangeal joint extension. Clin Biomech (Bristol, Avon) 13:190-194.

43. Chougala A, Phanse V, Khanna E, Panda S. Screening Of Body Mass Index And Functional Flatfoot In Adult : An Observational Study Quick Response code. 2015;3(3):1037-41.

\section{Acknowledgement:-}

I would like to acknowledge, Ms.Deepa Menon.K Research scholar, Department of Bioinformatics, Sri

Ramachandra University for helping me in statistical analysis, without which this research would be incomplete. 